\title{
Komunikasi Simbolik dalam Penggunaan Upakara Yajña pada Ritual Hindu
}

\author{
Ida Ayu Tay Puspa ${ }^{1}$, Ni Putu Sinta Dewi², Ida Bagus Subrahmaniam Saitya ${ }^{3}$ \\ ${ }^{13}$ Fakultas Dharma Duta, ${ }^{2}$ Fakultas Brahma Widya \\ Institut Hindu Dharma Negeri Denpasar
}

\begin{abstract}
Hindus in carrying out rituals by way of karma and devotional service use ceremonial means called upakara or also called banten. Upakara presented to Ida Sang Hyang Widhi Wasa and its manifestations must be based on sincerity which is also adjusted to the level of yajña that can be carried out by Hindus both at the level of Nista, masdya, and the main. In the process of making and offering upakara there is symbolic communication, namely the symbol of devotion to God / Ida Sang Hyang Widhi Wasa by sparking gratitude to Him. Symbolic communication is communication that uses symbols that have been agreed upon by the community or a certain group. The message will have the same meaning if it is in accordance with the agreement set by a certain community.

Every communication process that is interwoven between individuals with one another means becomes the main element. Whereas language has a very strategic position and the mind becomes a very significant thing in identifying and interpreting a symbol

In the yajña or bebantan upakara there are several principles which are principle, namely the principle of name or designation, it can also be the sound equation in the material of the bull itself. The principle of this name means that the elements of the bull when viewed from the name or sound contain the meaning that is in accordance with the purpose of the upakara.
\end{abstract}

Keywords Symbolic Communication, Yajña Upakara, Hindu Ritual

\section{PENDAHULUAN}

Agama Hindu di Bali dalam setiap pelaksanaan ritual upacara keagamaan tidak pernah terlepas dari keyakinan hari suci dan penggunaan sarana upacara/upakara yajña yang dapat menghubungkan antara dirinya dengan Yang dipuja. Dengan demikian, dapat

\footnotetext{
1 dayu.tary@yahoo.com

2 niptsinta.dewi@gmail.com

${ }^{3}$ Ibsubrahmaniam.saitya@gmail.com
} 
ditemukan dalam setiap ritual yang dilakukan oleh masyarakat Bali Upakara sebagai komponen utama yang selalu berhubungan dengan ritual. Kedua hal ini tentu tidak dapat dipisahkan antara satu dengan yang lainnya, namun untuk penggunaan sarana upacara/upakara tentu harus disesuaikan dengan kemampuan masing-masing individu yang dalam agama Hindu hal itu disebut dengan tingkatan yajña yaitu Nista, Nista, dan Utama dalam bahasa Bali disebut dengan alit, Nista, dan agung.

Penggunaan Upakara Yajña

dalam setiap ritual upacara dapat dikatakan sebagai proses komunikasi simbolik yang dilakukan antara pemuja dengan yang dipuja. Pada Upakara Yajña baik dalam proses pembuatannya maupun dalam penggunaannya adanya suatu komunikasi simbolik yang tersirat secara tidak langsung. Hal ini menunjukkan bahwa komunikasi simbolik sering terjalin di tengah penggunaan upakara yajña dalam ritual keagamaan.

Proses komunikasi pada hakikatnya merupakan proses penyampaian pikiran atau perasaan oleh komunikan kepada komunikator (oleh seseorang kepada orang lain). Menurut Effendy (2007: 11-16) dikatakan bahwa proses komunikasi tersebut dilakukan dengan beberapa tahapan yang teratur agar penyampaian pesan dari komunikator dapat diterima dengan baik oleh komunikan. Maka dari itu proses komunikasi terdiri atas dua tahap, meliputi proses komunikasi primer dan proses komunikasi sekunder.

Berdasarkan hal tersebut secara umum proses komunikasi simbolik dalam penggunaan upakara yajña dalam ritual keagamaan memiliki dua tahap yaitu proses secara primer dan sekunder.
Proses secara primer ini biasanya sebagai contoh dapat dilihat dengan pembuatan upakara berupa himbauan dari banjar atau prajuru adat kepada masyarakat untuk masing-masing KK membuat upakara dalam pelaksanaan ritual mecaru terkait misalnya dengan Tilem Keenen, Tilem Kesanga di Desa dengan memberikan informasi secara langsung. Adapun jika ditinjau dari proses sekunder yang terjadi adalah dalam mempertegas hal tersebut, maka berupa surat dan microphone digunakan dalam menghindari kesenjangan informasi dan komunikasi.

Komunikasi Simbolik dalam penggunaan upakara yajña dalam ritual Hindu adalah simbol rasa bhakti kepada Tuhan/Ida Sang Hyang Widhi Wasa dengan cara mencetuskan rasa terimakasih kepadaNya. Oleh karena dalam Hindu diyakini bahwa manusia sedari lahir telah membawa tiga hutang yang disebut dengan Tri Rna. Selain itu pula mengamalkan ajaran Weda, juga sebagai salah satu cara untuk menghubungkan diri dengan Ida Sang Hyang Widhi Wasa. Hal yang lebih siginifikan adalah untuk penyucian dan sebagai peningkatan kualitas diri. Itulah upakara dikatakan sebagai persembahan agung yang berlandaskan ketulusiklasan.

\section{PEMBAHASAN}

\section{Pengertian Komunikasi Simbolik}

Komunikasi adalah proses penyampaian pesan atau gagasan serta pengertianpengertian baik secara verbal dan non verbal. Secara sederhana komunikasi dapat terjadi apabila ada kesamaan antara penyampai pesan dan orang yang menerima pesan. Komunikasi atau communicate berasal dari bahasa Latin "communis". Communis atau dalam bahasa Inggrisnya "commun" yang 
artinya sama. Ini berarti komunikasi terjadi apabila ada kesamaan antara komunikator dan komunikan. Hal yang terpenting dalam komunikasi ialah bagaimana caranya agar suatu pesan yang disampaikan komunikator itu menimbulkan dampak atau efek tertentu pada komunikan (Effendy, 2008 : 6).

Komunikasi merupakan proses sosial karena komunikasi selalu melibatkan manusia dalam berinteraksi. Yang artinya komunikasi selalu melibatkan pengirim dan penerima yang memainkan peranan penting dalam proses komunikasi. Komunikasi juga dinyatakan sebagai proses interaksi simbolik, yaitu mengemas pikiran sebagai isi pesan dengan bahasa lambang. Lambang atau simbol adalah sesuatu yang digunakan untuk menunjuk sesuatu lainnya berdasarkan kesepakatan sekelompok orang. Lambang meliputi kata-kata atau pesan verbal, perilaku non verbal, objek yang maknanya disepakati bersama. Dalam pemberian arti pada simbol adalah suatu proses komunikasi yang dipengaruhi oleh kondisi sosial budaya yang berkembang pada suatu masyarakat (Cangara, 2008:99). Lambang yang paling umum digunakan dalam komunikasi antar manusia adalah bahasa verbal dalam bentuk kata-kata, kalimat, angkaangka, atau tanda-tanda lainnya yang bertujuan untuk keperluan membujuk atau minta tolong, selain itu ada juga lambang-lambang yang bersifat non verbal yang dapat digunakan dalam komunikasi seperti gesture (gerak tangan, kaki, atau bagian tubuh lainnya). Lambang-lambang non verbal dimaksudkan untuk memperkuat makna pesan yang disampaikan (Riswandi, 2009: 6-26).
Komunikasi simbolik merupakan komunikasi yang menggunakan simbolsimbol yang sudah disepakati oleh masyarakat atau suatu kelompok tertentu. Pesan akan memiliki makna yang sama jika sesuai dengan kesepakatan yang sudah ditetapkan oleh masyarakat tertentu. Seperti pada Upacara Macaru Mabiasan di Pura Balai Agung Desa Adat Petang merupakan simbolisasi umat untuk mempersembahkan santapan atau sesaji agar terciptanya keharmonisan dan kesucian desa, serta unsur-unsur negatif dari para butakala menjadi netral (somya). Pada Upacara Macaru Mabiasan upakara yang digunakan memiliki simbol-simbol atau maknamakna tertentu (Purpitadewi, 2017:8).

\section{Pengertian Upakara Yajña}

Ketika berbicara mengenai upakara yajña yang terdapat dalam benak pikiran adalah sebuah sarana dalam melakukan pemujaan terhadap Tuhan/Ida Sang Hyang Widhi Wasa. Pemahaman mengenai upakara yajña ini digunakan yang disesuaikan dengan desa, kala, patra. Dari segi bentuk pembuatan pun memiliki perbedaan namun tetap mengandung esensi yang sama.

Menurut Yogagiri, (2013: 1) upakara sering dikenal dengan banten, upakara berasal dari kata "upa" dan "kara", yaitu upa berarti berhubungan dengan, sedangkan Kara berarti perbuatan/pekerjaan (tangan). Upakara merupakan bentuk pelayanan yang diwujudkan dari hasil kegiatan kerja berupa materi yang dipersembahkan atau dikuburkan dalam suatu upacara keagamaan. Sanjaya, (2010: 53) mengatakan Yajña berasal dari sebuah kata dalam bahasa Sanskerta, yaitu yaj 
yang berarti memuja, menyembah, atau berdoa. Yajña juga berarti persembahan suci yang tulus iklas. Persembahan suci ini dalam pelaksanaannya memerlukan dukungan sikap mental yang suci pula. Ydjyna mengandung unsur perbuatan (karma), ketulus iklasan, kesadaran, dan persembahan.

Dari hal tersebut dapat dipahami bahwasanya upakara yajña adalah persembahan suci yang biasanya dibuat/dikerjakan dengan bahan-bahan yang ada dengan dibentuk, dirangkai, dan diatur sedemikian rupa sesuai aturan, sehingga berwujud persembahan yang indah dilihat. Dalam bentuknya yang sedemikian rupa terkandung unsur komunikasi simbolik antara yang membuat dengan yang dibuatnya. Hal ini dapat dilihat dengan pemahaman akan makna dalam proses pembuatan sarana upacara/upakara yajña itu sendiri. Dalam pustaka Bhagavadgītā IX.26 menyebutkan tentang unsur-unsur pokok persembahan itu adalah:

patram pușpam phalam toyam

yo me bhaktyā prayacchati, tad aham bhakti-upahrtam aśnāmi prayatātmanaḥ.

Terjemahannya:

Siapapun yang dengan sujud bhakti kepada-Ku mempersembahkan sehelai daun, sekuntum bunga, sebiji buahbuahan, seteguk air, Aku terima sebagai bhakti persembahan dari orang yang berhati suci (Pudja, 1999:239).

Dari sloka tersebut dapat diamati hal-hal sebagai berikut:

1. Daun; dapat berupa janur, ron, tlujungan/daun pisang dan daun yang lainnya yang disebut dengan plawa, sirih, daun pilasa, dan sebagainya.
2. Buah; dapat berupa buah-buahan seperti: kelapa, padi, tingkih, pangi, pinang, pisang, jenis kacang-kacangan, serta semua jenis buah-buahan yang dapat dimakan.

3. Bunga; dapat berupa segala bentuk dan jenis bunga-bungaan yang harum, segar, dan yang ditetapkan dan diperkenankan untuk banten.

4. Air berupa zat cair seperti: air untuk membersihkan segala sarana banten, air kelapa, arak berem tuak, madu, empehan/susu, air kumkuman dan lainnya.

5. Api/Gni: yang berfungsi sebagai pembakar sarana upakara berupa kemenyan, majagau, serbuk, kayukayuan seperti cendana, dupa, lilin, dan lainnya.

Yogagiri, (2013: 2) mengatakan bahanbahan upakara untuk persembahan atau korban suci tersebut, semuanya diambil dari ciptaan Ida Sang Hyang Widhi Wasa di dunia ini dan kesemuanya itu dapat dibedakan menjadi tiga jenis yaitu:

1. Mataya

Sesuatu yang tumbuh. Bahan-bahan ini terdiri dari tumbuh-tumbuhan yang dipakai sarana upakara terdiri dari berbagai jenis daun, bunga, dan buahbuahan.

\section{Mantiga}

Sesuatu yang lahir dua kali seperti telur itik, ayam, angsa, dan lainnya.

\section{Maharya}

Sesuatu yang lahir sekali langsung menjadi binatang, seperti binatangbinatang berkaki empat misalnya sapi, babi, kerbau, dan lain sejenisnya.

Dalam setiap pelaksanaan ritual penggunaan upakara yang memiliki esensi dan makna dengan berlandaskan cinta kasih dan ketulus iklasan akan memberikan jalan hikmat keberlangsungan ritual yang 
dilaksanakan. Untuk itu penting bagi masyarakat agama Hindu dalam memiliki landasan ketulusiklasan dan juga cinta kasih. Tentunya semua harus seimbang antara esensi dan makna dalam pembuatan serta penggunaan upakara maupun ketulus iklaskan dalam mempersembahkannya.

\section{Fungsi Komunikasi Simbolik dalam Penggunaan Upakara Yajña Pada Ritual Hindu}

Komunikasi simbolik secara umum selalu berkaitan dengan penggunaan tanda/lambang yang bersifat fisik, dapat diinterpretasikan, dipersepsikan, dan ditelaah oleh indera manusia. Dalam penggunaan sarana upakara yajña proses interaksi simbolik terjadi. Seringkali umat beragama Hindu menggunakan simbol yang disebut dengan upakara yajña sebagai mediator utama dalam menghubungkan antara dirinya dengan yang dipuja. Simbolsimbol/jenis lambang yang dimaksud dalam komunikasi simbolik adalah berupa lambang gerak, lambang suara, lambang warna, lambang gambar, lambang angka, lambang bahasa, lambang huruf.

Adapun fungsi komunikasi simbolik dalam penggunaan upakara yajña adalah sebagai berikut:

\section{Sebagai alat konsentrasi}

Penggunaan upakara yajña sebagai alat konsentrasi, hal ini disebabkan oleh kemampuan yang dimiliki oleh manusia sangat terbatas adanya, dalam usaha untuk mendekatkan hubungan dengan Ida Sang Hyang Widhi Wasa dan segala manifestasi-Nya, untuk menyampaikan rasa terimakasih karena berbagai anugerah yang diberikan. Dengan melihat banten/upakara, pikirannya sudah teringat dan terarah pada yang dihadirkan atau dipuja. Penggunaan upakara sebagai alat konsentrasi, umumnya dilakukan oleh mereka yang menempuh jalan melalui bhakti marga dan karma marga dalam ajaran catur marga. Bagi bhakti marga mengutamakan penyerahan diri dan pencurahan rasa yang didasari dengan cinta kasih terhadap yang dipuja yaitu Ida Sang Hyang Widhi Wasa dan segala manifestasi-Nya, untuk mencapai kebahagiaan yang tertinggi.

Pada karma marga, menekankan rasa bhaktinya pada pengabdian yang berwujud kerja tanpa pamrih. Kerja merupakan simbol hidup, hidup adalah untuk beryajña, karena melalui yajñalah semua yang hidup di dunia ini diciptakan oleh Ida Sang Hyang Widhi Wasa pada zaman dahulu, seperti yang termuat dalam Bhagavadgita berikut ini.

saha-yajñāḥ prajāḥ srșțtāa purovāca prajāpatih̆, anena prasavișyadhvam eșa vo 'stv ișța-kamā-dhuk. (Bhagavadgītā III.10)

\section{Terjemahannya:}

Sesungguhnya sejak dahulu dikatakan, Tuhan setelah menciptakanvmanusia melalui yajña, berkata: dengan (cara) ini engkau akan berkembang, sebagaimana sapi perah yang memenuhi keinginanmu (sendiri) (Pudja, 1999:84).

Penggunaan sarana upakara yajña sebagai alat konsentrasi jika dikaitkan dengan komunikasi simbolik seperti yang dikatakan sebelumnya bahwa sarana upakara yajña yang digunakan dengan sedemikian rupa akan menjadi penghubung komunikasi antara yang 
memuja dengan yang dipuja. Sehingga tercipta kekuatan akan keyakinan itu sendiri dan menghasilkan perasaanperasaan baru seperti ketenangan batin.

2. Upakara yajña sebagai persembahan atau kurban suci

Upakara sebagai persembahan, apabila ditujukan kehadapan yang lebih tinggi tingkatannya dari manusia. Disebut kurban suci apabila ditujukan kepada yang tingkatannya lebih rendah dari pada manusia seperti dalam pelaksanaan upacara bhuta yajña. Maksud dan tujuan dari persembahan atau kurban suci itu adalah sebagai pernyataan dari perwujudan rasa terima kasih manusia kehadapan Ida Hyang Widhi Wasa dan segala manifestasi-Nya. Penggunaan upakara yajña sebagai persembahan atau kurban suci ini ketika ditelaah dari sudut komunikasi simbolik itu sendiri memberikan gambaran bahwa manusia memang tidak pernah terlepas dari penggunaan simbol-simbol sebagai wujud dari keyakinannya. Ketika ditinjau lagi bahwa dapat dipahami umat beragama Hindu meyakini keberadaan Ida Sang Hyang Widhi Wasa beserta seluruh manifestasinya. Dalam melakukan komunikasi itu tentu perlu adanya ritual disesuaikan dengan hari suci yang diyakini dan penggunaan sarana upakara, dibuat dengan bentuk sedemikian rupa. Manusia dalam menghubungkan dirinya dengan Tuhan tentu memiliki keterbatasan untuk itu sarana upakara yajña menjadi instrumen utama dalam berkomunikasi dengan Ida Sang Hyang Widhi Wasa beserta manifestasinya.

Makna Komunikasi Simbolik dalam Penggunaan Upakara Yajña pada Ritual Hindu
Setiap proses komunikasi yang terjalin antara individu yang satu dengan lainnya makna menjadi elemen utama. Sedangkan bahasa memiliki posisi yang sangat strategis dan pikiran menjadi hal yang sangat signifikan dalam mengidentifikasi maupun menginterpretasikan sebuah simbol. Menurut Klasionotes, (2018:4) dikatakan dengan menggunakan simbol kita bisa menyampaikan dan menerima maknamakna yang jelas dan mendalam dalam sebuah komunikasi. Komunikasi melalui simbol juga ditemui dalam bentuk karya seni seperti lukisan, patung, musik, dan tarian. Tekstur, bentuk, pencahayaan, tata rias, gerakan. Semua memiliki makna meski tanpa adanya kata-kata.

Dalam upakara yajña atau bebantenan itu terdapat beberapa hal yang bersifat prinsip yaitu prinsip nama atau sebutan, bisa pula persamaan bunyi dalam bahan dari banten itu sendiri. Prinsip nama ini memiliki arti bahwa unsur-unsur banten itu bila dilihat dari nama atau bunyi mengandung makna yang sesuai dengan tujuan upakara tersebut. Contoh dari penggunaan prinsip nama adalah sebagai berikut:

a. Daun Kayu Sisih, biasanya digunakan untuk banten Byakala, memiliki makna menyisihkan pengaruhpengaruh negatif

b. Daun Kayu Tulak, juga terdapat dalam banten byakala, yang bermakna untuk menolak (tulak) segala kotoran atau pengaruh negatif yang ada dalam tubuh manusia.

c. Pangulapan, berasal dari kata ulap yang artinya melambaikan tangan dengan maksud memanggil (ngulapulap). Maksudnya adalah memanggil Ida Bhatara. Jadi banten Pangulapan adalah sarana untuk mengundang atau 
memanggil Ida Bhatara agar hadir dalam upacara yajña yang dilakukan.

d. Pangambean, berasal dari kata ambe yang berarti menyongsong atau memegang. Banten pengambean berfungsi sebagai sarana penyambutan, penjemputan, penyongsong Ida Bhatara yang telah hadir dalam upacara yajña tersebut.

e. Panyeneng, berasal dari kata nyeneng yang berarti duduk. Jadi fungsi dari penyeneng adalah sebagai stana Ida Bhatara.

Demikian beberapa contoh banten yang menggunakan prinsip nama. Disamping itu terdapat prinsip rupa, yaitu prinsip yang menunjukan pada bentuk ataupun warna dalam banten. Contoh sarana upakara yang menggunakan prinsip rupa ini adalah:

a. Bagian-bagian Porosan seperti daun sirih (hijau) simbol bhatara Wisnu, pinang (merah) simbol Bhatara Brahma dan pamor (putih) simbol Bhatara Siwa.

b. Bagian-bagian daksina seperti; tampak simbol dari cakra berputar atau swastika.

c. Tumpeng adalah simbol gunung yang sebagai sumber kesuburan, kemakmuran, karena sebagai penyimpan air yang murni.

Disamping itu dalam upakara atau banten juga terdapat konsep Tri Angga dalam pembuatan banten sorohan. Konsep Tri Angga ini adalah konsep berdasarkan tiga bagian dari tubuh yaitu kepala pada bagian atas, badan pada bagian tengah, dan kaki pada bagian bawah. Prinsip Tri Angga ini sebagai dasar untuk menentukan besar kecilnya bagian-bagian dari banten tersebut sehingga membentuk suatu keharmonisan dan keseimbangan tubuh banten, jangan sampai kepala terlalu besar, badan terlalu kecil dan kaki besar pula. Ataukah sebaliknya kepala terlalu kecil, badan besar, dan kaki kecil. Hal tesebut tidak akan menimbulkan keseimbangan.

Titib, (2003: 134) menyatakan banten atau persembahan suci adalah persembahan yang dibuat dengan sarana tertentu, antara lain berupa: bunga, buah-buahan, daun tertentu seperti sirih, dan makanan seperti nasi dengan lauk pauk, jajan, dan sebagainya, disamping sarana yang sangat penting lainnya adalah air dan api berikut penjelasannya:

\section{a. Daksina}

Daksina disebut Yajñapatni yang artinya istri atau sakti dari pada yajña. Daksina juga digunakan sebagai persembahan/tanda terimakasih, selalu menyertai banten-banten yang agak besar, dan sebagainya perwujudan atau tapakan. Di dalam lontar yajña prakerti disebutkan bahwa daksina melambangkan Hyang Guru/Hyang Tunggal, kedua nama tersebut adalah nama lain Dewa Siwa. Dalam setiap penyelenggaraan upacara yajña harus selalu menggunakan Daksina. Banten daksina adalah sakti atau kekuatan dari stana Ida Sang Hyang Widhi Wasa.

\section{b. Kewangen}

Kewangen sebagai salah satu sarana persembahyangan adalah berfungsi untuk mengharumkan Ida Sang Hyang Widhi Wasa. Kewangen juga sebagai simbol penyembah kepada Ida Sang Hyang Widhi Wasa baik secara lahir maupun batin.

\section{c. Canang}

Canang merupakan sarana upakara yang memiliki beberapa bagian yaitu ceper sebagai wadah, plawa, Porosan, tebu, pisang, bunga, dan kekiping. Bunga memiliki makna ketulus iklasan hati dan pikiran yang suci dan bersih. Porosan 
bermakna simbol tri murti yaitu Brahma dilambangkan dengan buah pinang, Wisnu dilambangkan dengan daun sirih, dan Siwa dilambangkan dengan kapur. Urasari adalah jejahitan dari janur yang berbentuk Padma Asta Dala yaitu lambang Sthana Ida Sang Hyang Widhi Wasa dengan manifestasi-Nya yang menempati delapan penjuru mata angin. d. Segehan

Segehan biasanya pada saat menghaturkan dan setelah melakukan puja atau seha diperciki tirta atau tetabuhan, selain itu disertai dengan api takep yaitu dua potong sabut kelapa yang dipertemukan perutnya (bagian dalam sabut) berisi api. Takepan (cakupan) sabut kelapa ini sebagai simbolis "tampak dara" atau swastika yang memiliki makna menetralisir kekuatan negativ.

Dari beberapa pembahasan terkait makna yang terkandung dalam upakara yajña dapat dipahami bahwasannya pikiran memungkinkan seseorang memodifikasi interpretasi terhadap simbol-simbol tersebut. masing-masing orang memiliki cara yang berbeda dalam menginterpretasikan simbol yang satu dengan lainnya hal ini dikarenakan perbedaan subjektifitas. Walau demikian penggambaran secara umum terkait makna yang terkandung dalam sarana upakara telah dipahami oleh masyarakat Hindu walaupun dengan struktur bahasa yang berbeda namun memiliki makna yang sama.

\section{KESIMPULAN}

Penggunaan Upakara Yajña dalam setip ritual upacara dapat dikatakan sebagai proses komunikasi simbolik yang dilakukan antara pemuja dengan yang dipuja. Pada sarana Upakara Yajña baik dalam proses pembuatannya maupun dalam penggunaannya adanya suatu komunikasi simbolik yang tersirat secara tidak langsung. Hal ini menunjukan bahwa komunikasi simbolik sering terjalin ditengah penggunaan upakara yajña dalam ritual keagamaan.

Komunikasi simbolik dalam upakara yajña pada ritual Hindu menjadi keseharusan yang harus dipahami bahwa kita tidak pernah dan akan selalu menggunakan simbol-simbol yang terdapat pada sarana upakara dalam berinteraksi dengan Tuhan. Untuk itu dalam pembuatan dan penggunaannya sudah semestinya mengikuti aturan yang berlaku sesuai dengan acuan lontar.

\section{DAFTAR PUSTAKA}

Cangara, H. Hafied, 2014. Pengantar IImu Komunikasi. Jakarta: PT Raja Grafindo Persada.

Mulyana, Deddy. 2008. Komunikasi Suatu Pengantar. Bandung: PT. Remaja Rosda Karya.

Dharmayasa. 2012. Bhagavad Gita. Denpasar: Yayasan Dharma Sthapanam.

Effendy, Onong Uchjana, 2008. Dinamika Komunikasi. Bandung: PT Remaja Rosdakarya.

Effendy, Onong Uchjana. 2003. Ilmu. Teori dan Filsafat Komunikasi, Bandung: Citra Aditya Bakti.

Effendy, Onong Uchjana. 2007. Ilmu Komunikasi Teori dan Praktek. Bandung: PT Remaja Rosdakarya.

Klasionotes. 2018: Komunikasi Simbolik Penggunaan Simbol dalam Komunikasi. Malang: https://klasionotes.wordpress.co $\mathrm{m}$

Pudja, G.1999. Bhagavadgītā. Surabaya: Pāramita.

Puspitadewi, Gusti Ayu Made Disia. 2017. Komunikasi Simbolik pada 
Pelaksanaan Upacara Mecarau Mabiasan di Desa Adat Petang Kecamatan Petang Kabupaten Badung. Tesis IHDN Denpasar.

Putra, Mas. 1998. Panca Yajña. Surabaya: Paramitha.

Riswandi, 2009. Ilmu Komunikasi. Jakarta: Graha IImu.

Titib, I Made. 2003. Teologi dan Simbolsimbol dalam Agama Hindu. Surabaya: Badan Litbang Parisada Hindu Dharma Indonesia Pusat bekerjasama dengan paramita.

Triguna. 2000. Teori Tentang Simbol. Denpasar: Widyadharma.

Widjaja. 2010. Komunikasi dan Hubungan Masyarakat. Jakarta: Bumi Aksara.

Sanjaya, Putu. 2010. Acara Agama Hindu. Surabaya: Paramita

Yogagiri. 2013. Upakara dalam Upacara Hindu. Denpasar: http://blog.isidps.ac.id

Titib, I Made. 2003. Teologi dan SimbolSimbol dalam Agama Hindu. Surabaya: Paramita 